\title{
Glucagon Measurement
}

National Cancer Institute

\section{Source}

National Cancer Institute. Glucagon Measurement. NCI Thesaurus. Code C74859.

The determination of the amount of glucagon hormone present in a sample. 